\title{
ANALISIS NASKAH ROBOHNYA SURAU KAMI \\ DAN PENGGUNAANNYA UNTUK MENYUSUN MODEL MENULIS NASKAH DRAMA DI UNIVERSITAS WIRALODRA INDRAMAYU (Eny Tarsinih)
}

\section{ABSTRACT}

This research is motivated by the importance of Indonesian drama script of transformation result and its use in developing a model to write a drama script. The problem in this study were (1) how the structure of Indonesian drama script of transformation results? and (2) Is the Indonesian drama script transformation results can be used to create a model for writing a drama script at the Wiralodra University?

The background of theory in this research include (1) the elements of drama; (2) the transformation of a drama script; and (3) model of writing drama script.

Another purpose of this research is to get empirical evidence about the Indonesian drama script of transformation result toward write a drama script modeling. This qualitative research study took place at the Wiralodra University Indramayu academic year 2013/2014, with a sampling technique was purposive sampling. Data collection technique using content analysis techniques and the study of literature. While the results are presented in descriptive form. The conclusions of this research were (1) the structure of the drama script is the result of a transformation consist of an overview, plot, actors, background, themes, values, attitudes author, and type of text, the text contains the main text and support text or side, consists of three parts, namely the opening of the story, part of the story, and the cover story. While the drama script of the text poetry, the presence of outer and inner structures are transformed into a drama script. (2) The results Indonesian drama script of this transformation result can be used to create a model for writing drama script among students at the Wiralodra University Indramayu.

\section{Keywords: Elements of Drama, Transformation, and Drama Script Writing}

\section{Pendahuluan}

Pembelajaran drama dianggap sulit dan memakan waktu yang lama, sehingga sering tersingkirkan oleh prosa dan puisi. Jarang para pengajar sastra yang mengedepankan drama, dibanding genre sastra lain. Padahal sesungguhnya drama itu seni yang kompleks. Dari prosa dan puisi dapat diubah menjadi drama, yang tidak kalah menarik. Menurut Waluyo (2002) drama secara harfiah berarti berbuat atau bertindak (dari bahasa Yunani: draomai). Drama merupakan tiruan kehidupan manusia yang diproyeksikan di atas pentas. Drama sebagai teks merupakan bagian dari karya sastra. Ciri khas drama dibandingkan dengan genre sastra lain adalah adanya dialog dan orientasi pada seni pertunjukan. Oleh karena itu, drama dapat dianggap sebagai suatu karya yang memiliki dua dimensi, yakni dimensi sastra dan dimensi pertunjukan.

Di sekolah-sekolah, naskah drama paling tidak diminati. Dalam penelitian Prof. Dr. Yus Rusyana disimpulkan bahwa minat siswa dalam membaca karya sastra yang terbanyak adalah prosa, menyusul puisi, baru kemudian drama. Perbandingannya adalah 6:3:1 (1979). Hal ini disebabkan karena menghayati naskah drama yang berupa dialog itu cukup sulit dan harus tekun. Dengan pementasan atau pembacaan oleh orang yang terlatih, hambatan tersebut kiranya dapat diatasi. Penghayatan naskah drama lebih sulit daripada penghayatan naskah prosa dan puisi.

Menulis naskah drama merupakan kegiatan menuangkan pikiran berupa tulisan menjadi dialog. Namun ternyata pada 
praktiknya dalam pembelajaran menulis drama, mahasiswa banyak menemukan kesulitan. Kesulitan yang dirasakan saat pembelajaran menulis naskah drama di antaranya menentukan ide cerita, menciptakan dialog antartokoh, menentukan karakter tokoh, mengembangkan cerita, menentukan konflik dan menentukan akhir cerita. Oleh karena itu, perlu adanya terobosan baru untuk membantu kesulitan mahasiswa dalam pembelajaran menulis naskah drama. Salah satu alternatif dalam membantu kesulitan mereka yaitu merancang pembelajaran kreatif yang bisa memudahkan mahasiswa mencapai kompetensi yang diinginkan. Salah satunya yaitu dengan menyediakan model, metode, teknik, media, atau bahan pembelajaran yang sesuai untuk menulis naskah drama.

Pada penelitian ini akan dilakukan dengan menganalisis naskah Robohnya Surau Kami dan penggunaannya untuk menyusun model menulis naskah drama. Naskah yang dianalisis yaitu dalam bentuk cerpen dan naskah drama karena naskah ini bentuk transformasi yang ditulis oleh orang yang berbeda. Bukan hal yang asing ketika kini banyak karya sastra yang ditransformasi seperti dijadikan film, sebaliknya naskah film ditulis menjadi novel seperti yang dilakukan Seno Gumira Ajidarma dalam Biola Tak Berdawai. Selain itu, ada juga sebuah puisi bisa dibuat menjadi video klip. Jauh sebelumnya, banyak puisi yang ditransformasi menjadi sebuah lagu seperti pada "Aku Ingin" karya Sapardi Djoko Damono. Hal tersebut menjadi salah satu alasan kuat bagi peneliti untuk menggunakan teknik transformasi dalam pembelajaran menulis naskah drama pada mahasiswa. Pembicaraan tentang drama naskah merupakan dasar dari telaah drama. Untuk itu saya menganalisis naskah Robohnya Surau Kami dan penggunaannya untuk menyusun model menulis naskah drama di Universitas Wiralodra Indramayu.

\section{Kajian Pustaka}

\section{Pengertian Drama}

Drama adalah kualitas komunikasi, situasi, action, (segala apa yang terlihat dalam pentas) yang menimbulkan perhatian, kehebatan (exciting), dan ketegangan pada pendengar/penonton (Harymawan, 1986). Sedangkan Waluyo (2002), drama secara harfiah berarti berbuat atau bertindak (dari bahasa Yunani: draomai). Drama merupakan tiruan kehidupan manusia yang diproyeksikan di atas pentas. Drama sebagai teks merupakan bagian dari karya sastra. Ciri khas drama dibandingkan dengan genre sastra lain adalah adanya dialog dan orientasi pada seni pertunjukan. Oleh karena itu, drama dapat dianggap sebagai suatu karya yang memiliki dua dimensi, yakni dimensi sastra dan dimensi pertunjukan. Teks drama apabila dipentaskan akan menjadi sebuah drama. Di samping itu, teks drama dibuat memang untuk ditampilkan. Cerita dalam teks drama akan lebih mudah dimengerti ketika dipentaskan. Hal ini sejalan dengan pendapat Hassanuddin dalam Dewojati (2010), membatasi drama sebagai suatu genre sastra yang ditulis dalam bentuk dialog-dialog dengan tujuan untuk dipentaskan sebagai seni pertunjukan.

Dalam Kamus Besar Bahasa

Indonesia Edisi Keempat pada halaman 342, drama didefinisikan sebagai

1. komposisi syair atau prosa yang diharapkan dapat menggambarkan kehidupan dan watak melalui tingkah laku (akting) atau dialog yang dipentaskan;

2. cerita atau kisah, terutama yang melibatkan konflik atau emosi, yang khusus disusun untuk pertunjukan teater; dan

3. kejadian yang menyedihkan.

Pengertian yang pertama dan kedua berkaitan erat dengan drama pada penjelasan di atas, sedangkan pengertian yang ketiga sering kita jumpai dalam penggunaan seharihari, seperti ungkapan "Perpisahan antara anak dan ibunya sangat dramatis". Hal yang hampir mirip dikenakan juga pada istilah sinetron drama atau film drama. Penggunaan istilah drama yang memiliki arti kejadian 
menyedihkan berkaitan dengan asal mula drama di Yunani yang lebih didominasi oleh tragedi. Dari uraian di atas tampak bahwa istilah drama dapat berarti pertunjukan (panggung, sinetron, atau film), dapat juga berarti naskah. Dalam kesusastraan, drama cenderung diartikan sebagai naskah. Jika diartikan sebagai pertunjukan atau pementasan, berbagai bidang seni, seperti gerak, tari, dan musik telah berhimpun di dalamnya, tidak semata-mata seni sastra. Bahkan dalam sastra drama Indonesia masa Balai Pustaka, seperti drama Bebasari karya Rustam Effendi dikenal sebagai closet drama, yaitu karya sastra dalam bentuk drama yang hanya cocok untuk dibaca, tetapi tidak cocok untuk dipentaskan.

\section{Transformasi Naskah Drama}

Makna kunci untuk istilah "transformasi" adalah "perubahan", yaitu perubahan terhadap suatu hal atau keadaan. Jika "suatu hal atau keadaan" itu adalah budaya, budaya itulah yang mengalami perubahan. Perubahan budaya itu sendiri dapat mencakup satu atau beberapa aspek atau bahkan sebagian besar aspek budaya tersebut. Menurut Nurgiyantoro (1998), istilah "transformasi" diartikan sebagai "pemunculan, pengambilan, atau pemindahan unsur-unsur pewayangan ke dalam unsur-unsur fiksi dengan perubahan". Dengan kutipan pengertian tersebut, transformasi naskah drama yang dikaji berarti memunculkan, mengambil, atau memindah unsur-unsur legenda, puisi, cerpen, atau novel ke dalam unsur-unsur naskah drama dengan melakukan perubahan yang baru. Secara prinsipial unsur legenda, cerpen, dan novel memiliki kesamaan dengan unsur-unsur drama karena samasama berangkat dari cerita. Baik legenda, cerpen, dan novel memiliki unsur intrinsik yang terdiri dari alur, tokoh, latar, tema, bahasa, nilai-nilai dan pesan moral, serta sudut pandang. Penelitian ini mengkaji lima unsur karena mempunyai kemungkinan mengandung transformasi dari unsur-unsur legenda, cerpen, dan novel, yaitu alur, tokoh, latar, tema, dan nilai-nilai.

Wujud transformasi yaitu terjemahan, salinan, alih huruf, sahajaan, parafrase, dan adaptasi/saduran (Sudjiman, 1993). Transformasi itu adalah: pertama, menarik budaya etnis ke tataran budaya kebangsaan, dan kedua menggeser budaya agraris tradisional ke tataran budaya industri (Khayam dalam Esten, 1992). Transformasi dilakukan dengan melihat hubungan intertekstual dalam teks yang kita kaji. Hubungan intertekstual antara teks dengan hipogram/teks dasarnya dapat berupa ekpansi, konversi, modifikasi, dan ekserp (Sardjono dalam Pudentia, 1992).

Menurut Rifaterre (Pudentia, 1992: 72-73), ekspansi adalah mengubah unsurunsur pokok matrik kalimat menjadi bentuk yang lebih kompleks. Dalam kebanyakan kasus, ekspansi lebih dari sekadar repetisi, tetapi juga mencakup perubahan gramatikal, misalnya perubahan jenis kata (Riffaterre, 1978: 48-63). Secara sederhana ekspansi dapat diartikan sebagai perluasan atau pengembangan (Pradotokusumo, 1986: 62).

Menurut Riffaterre (Pudentia, 1992) konversi adalah mengubah unsur-unsur kalimat matrik dengan memodifikasikannya dengan sejumlah faktor yang sama. Konversi tampak nyata dalam tataran morfologi dan fonologi. Menurut Pradotokusumo (1986: 63) konversi adalah pemutarbalikan hipogram atau matriksnya.

Modifikasi atau pengubahan biasanya merupakan manipulasi pada tataran linguistik, yaitu manipulasi kata atau urutan kata dalam kalimat; pada tataran kesastraan, yaitu manipulasi tokoh (protagonis) atau alur (Pudentia, 1992: 72). Ekserp diartikan semacam intisari suatu unsur atau episode dari hipogram (Pudentia, 1992: 73).

\section{Teknik Menulis Naskah Drama}

Membuat naskah lakon sendiri tidak menguntungkan karena akan memperpanjang proses pengerjaan. Akan tetapi berkenaan dengan sumber daya yang dimiliki, membuat naskah sendiri dapat menjadi pilihan yang 
tepat. Untuk itu, seorang penulis harus mampu membuat naskah yang sesuai dengan kualitas sumber daya yang ada pada grup teater (drama) yang mereka miliki. Naskah semacam ini bersifat situasional, tetapi semua orang yang terlibat menjadi senang karena dapat mengerjakannya sesuai dengan kemampuan yang dimiliki.

Beberapa langkah di bawah ini dapat dijadikan acuan untuk menulis naskah drama.

\section{a. Menentukan Tema}

Tema adalah gagasan dasar cerita atau pesan yang akan disampaikan oleh pengarang kepada penonton. Tema, akan menuntun laku cerita dari awal sampai akhir. Misalnya tema yang dipilih adalah "kebaikan akan mengalahkan kejahatan", maka dalam cerita hal tersebut harus dimunculkan melalui aksi tokoh-tokohnya sehingga penonton dapat menangkap maksud dari cerita bahwa sehebat apapun kejahatan pasti akan dikalahkan oleh kebaikan.

\section{b. Menentukan Persoalan (Konflik)}

Persoalan atau konflik adalah inti dari cerita teater. Tidak ada cerita teater tanpa konflik. Oleh karena itu pangkal persoalan atau titik awal konflik perlu dibuat dan disesuaikan dengan tema yang dikehendaki. Misalnya dengan tema "kebaikan akan mengalahkan kejahatan," pangkal persoalan yang dibicarakan adalah sikap licik seseorang yang selalu memfitnah orang lain demi kepentingannya sendiri. Persoalan ini kemudian dikembangkan dalam cerita yang hendak dituliskan.

\section{c. Membuat Sinopsis (ringkasan cerita)}

Gambaran cerita secara global dari awal sampai akhir hendaknya dituliskan. Sinopsis digunakan pemandu proses penulisan naskah sehingga alur dan persoalan tidak melebar. Dengan adanya sinopsis maka penulisan lakon menjadi terarah dan tidak mengada-ada.

\section{d. Menentukan Kerangka Cerita}

Kerangka cerita akan membingkai jalannya cerita dari awal sampai akhir. Kerangka ini membagi jalannya cerita mulai dari pemaparan, konflik, klimaks sampai penyelesaian. Dengan membuat kerangka cerita maka penulis akan memiliki batasan yang jelas sehingga cerita tidak bertele-tele. William Froug (1993) misalnya, membuat kerangka cerita (skenario) dengan empat bagian, yaitu pembukaan, bagian awal, tengah, dan akhir. Pada bagian pembukaan memaparkan sketsa singkat tokoh-tokoh cerita. Bagian awal adalah bagian pengenalan secara lebih rinci masing-masing tokoh dan titik konflik awal muncul. Bagian tengah adalah konflik yang meruncing hingga sampai klimaks. Pada bagian akhir, titik balik cerita dimulai dan konflik diselesaikan. Riantiarno (2003), sutradara sekaligus penulis naskah Teater Koma, menentukan kerangka lakon dalam tiga bagian, yaitu pembuka yang berisi pengantar cerita atau sebab awal, isi yang berisi pemaparan, konflik hingga klimaks, dan penutup yang merupakan simpulan cerita atau akibat.

\section{e. Menentukan Protagonis}

Tokoh protagonis adalah tokoh yang membawa laku keseluruhan cerita. Dengan menentukan tokoh protagonis secara mendetil, maka tokoh lainnya mudah ditemukan. Misalnya, dalam persoalan tentang kelicikan, maka tokoh protagonis dapat diwujudkan sebagai orang yang rajin, semangat dalam bekerja, senang membantu orang lain, berkecukupan, dermawan, serta jujur. Semakin detil sifat atau karakter protagonis, maka semakin jelas pula karakter tokoh antagonis. Dengan menulis lawan dari sifat protagonis maka karakter antagonis dengan sendirinya terbentuk. Jika tokoh protagonis dan antagonis sudah ditemukan, maka tokoh lain baik yang berada di pihak protagonis atau antagonis akan mudah diciptakan.

\section{f. Menentukan Cara Penyelesaian}

Mengakhiri sebuah persoalan yang dimunculkan tidaklah mudah. Dalam beberapa lakon ada cerita yang diakhiri dengan baik tetapi ada yang diakhiri secara tergesa-gesa, bahkan ada yang bingung mengakhirinya. Akhir cerita yang 
mengesankan selalu akan dinanti oleh penonton. Oleh karena itu tentukan akhir cerita dengan baik, logis, dan tidak tergesagesa.

\section{g. Menulis}

Setelah semua hal disiapkan maka proses berikutnya adalah menulis. Mencari dan mengembangkan gagasan memang tidak mudah, tetapi lebih tidak mudah lagi memindahkan gagasan dalam bentuk tulisan. Oleh karena itu, gunakan dan manfaatkan waktu sebaik mungkin.

\section{Cara Penelitian}

\section{Sumber Data dan Data Penelitian}

Sumber data dalam penelitian ini adalah naskah-naskah drama Indonesia hasil transformasi. Data dalam penelitian ini yaitu: hasil transformasi dengan judul yang sama dari cerpen karya A.A. Navis ke naskah drama "Robohnya Surau Kami" karya Hermana HMT.

\section{Teknik Pengambilan Sampel}

Teknik pengambilan sampel dalam penelitian ini dengan cara purposive sampling, yaitu teknik penentuan sampel dengan pertimbangan tertentu (Sugiyono, 2011). Pertimbangan dalam penelitian ini adalah mengetahui kualitas naskah-naskah drama Indonesia hasil transformasi maka sampel ditentukan dengan tujuan tersebut. Sampel ini lebih cocok digunakan untuk penelitian kualitatif, atau penelitianpenelitian yang tidak melakukan generalisasi.

\section{Teknik Pengumpulan Data}

Teknik pengumpulan data dalam penelitian ini menggunakan teknik analisis konten dan studi kepustakaan. Cara memeroleh data-data yang terdapat dalam naskah drama, peneliti membaca naskah drama terlebih dahulu. Setelah memeroleh data-datanya, kemudian data-data tersebut dicatat dan dianalisis. Teknik analisis, yaitu peneliti sebagai instrumen kunci melakukan pencatatan dan penganalisisan data, sedangkan teknik pustaka, yaitu pengumpulan data yang menggunakan sumber-sumber tertulis untuk memeroleh data.

\section{Teknik Analisis Data}

Analisis data dalam penelitian kualitatif dilaksanakan secara terus-menerus, sejak pengumpulan data di lapangan sampai waktu penulisan laporan penelitian. Langkah awal adalah membaca naskah drama. Pada tahap ini peneliti dapat menemukan arti secara linguistik. Selanjutnya yaitu peneliti menganalisis lebih lanjut naskah-naskah drama hasil transformasi tersebut untuk mengungkapkan struktur drama naskah dan cara mentransformasi teks sastra.

Langkah kerja dalam penelitian ini dibagi dalam tiga tahapan. Tahap pertama adalah mendeskripsikan teks cerita sebelumnya yaitu naskah cerpen. Tahap kedua adalah menguraikan unsur-unsur yang membangun struktur cerita sebelumnya dan naskah drama. Tahap ketiga adalah mengungkap transformasi yang terjadi pada naskah drama serta mengungkap resepsi sastra dalam naskah drama. Hasil penelitian disajikan dalam bentuk deskriptif.

\section{Hasil Penelitian \\ Pembahasan Transformasi Teks \\ Robohnya Surau Kami}

Transformasi teks yang berawal dari cerpen yang ditulis oleh Ali Akbar Navis pada tahun 1956 ke dalam bentuk naskah drama oleh Hermana HMT. Perubahan yang terjadi lebih banyak ke dalam tokoh dan penokohan dibanding alur cerita. Karena kejadian-kejadian dalam cerita ini hampir sama, namun ada pengembangan alur dari ketua pentas. Hermana HMT membuat pengembangan-pengembangan tokoh, memperbanyak tokoh-tokoh yang terlibat, dan ada salah satu tokoh yang diubah tetapi bukan tokoh sentral. Tokoh-tokoh tersebut adalah sebagai berikut.

\section{Kakek}

\section{: rajin beribadah tetapi tidak memedulik}


Suara

an anak

dan

Perempuan

pemberi

istrinya

yang taat

: malaikat

Pembaca Doa 1, 2, \& 3 : rajin

berdoa

Laki-laki

: rajin

bersodakoh

kabar

Ajo Sidi

: pembual

cerita

Transformasi

berupa penghipograman pola alur cerpen ke dalam naskah drama. Pola alur cerpen yang terdiri dari pemaparan, konflik awal, klimaks, penurunan konflik, dan penyelesaian. Cerpen menyimbolkan perjalanan hidup manusia yang ditransformasikan menjadi alur naskah drama yang terdiri dari prolog, adegan,

Haji Saleh

: sombong

dan provokator

babak, dan epilog.

Transformasi latar dunia cerpen ke

Pendongeng 1 dan 2 : gemar

bercerita

Orang-orang

: kompak

Tokoh lain 1, 2, \& 3 : pendukung

Haji Saleh

Seseorang

: pemberi

kabar

Seorang perempuan : pemberi

kabar

Perempuan 1, 2, 3, \& 4 : pemberi kabar dalam naskah drama berupa penempatan tokoh-tokoh cerita ke dalam latar dunia drama yang latar sebenarnya adalah panggung hanya dibuat seolah-olah latar sesungguhnya, baik latar tempat maupun waktu.

Transformasi nilai yang berupa tindakan dan tujuan melangsungkan hidup berupa perbedaan cara hidup tokoh, pesan moral, dan pengongkretan karakter tokoh cerpen ke dalam naskah drama.

Transformasi Teks Robohnya Surau Kami

\begin{tabular}{|c|c|c|c|c|c|c|}
\hline \multirow{2}{*}{$\begin{array}{l}\text { SITUASI } \\
\text { CERPEN }\end{array}$} & \multicolumn{5}{|c|}{ TRANSFORMASI } & \multirow{2}{*}{$\begin{array}{c}\text { SITUASI NASKAH } \\
\text { DRAMA }\end{array}$} \\
\hline & ALUR & $\begin{array}{l}\text { PENO- } \\
\text { KOHAN }\end{array}$ & LATAR & TE-MA & $\begin{array}{l}\text { NILAI- } \\
\text { NILAI }\end{array}$ & \\
\hline $\begin{array}{l}\text { Seseorang } \\
\text { yang } \\
\text { menunjuk- } \\
\text { kan jalan ke } \\
\text { rumahnya, } \\
\text { melewati } \\
\text { surau dan } \\
\text { bercerita } \\
\text { tentang } \\
\text { keadaan } \\
\text { surau. Ada } \\
\text { seorang } \\
\text { kakek tua } \\
\text { sebagai } \\
\text { penjaga } \\
\text { garin yang } \\
\text { hidupnya } \\
\text { hanya dari }\end{array}$ & $\begin{array}{l}\text { alur cerpen } \\
\text { dikisah-kan } \\
\text { secara } \\
\text { langsung } \\
\text { pada tokoh- } \\
\text { tokoh yang } \\
\text { ada dalam } \\
\text { cerita } \\
\text { tersebut. } \\
\text { Hanya } \\
\text { dicerita-kan } \\
\text { menggu- } \\
\text { nakan alur } \\
\text { campur-an, } \\
\text { karena ada } \\
\text { alur mundur } \\
\text { dan alur maju } \\
\text { di dalam-nya. }\end{array}$ & $\begin{array}{l}\text { Perubahan } \\
\text { tokoh } \\
\text { terjadi } \\
\text { pada suara } \\
\text { Tuhan } \\
\text { menjadi } \\
\text { suara } \\
\text { malaikat, } \\
\text { tokoh aku } \\
\text { menjadi } \\
\text { tokoh laki- } \\
\text { laki, dan } \\
\text { tokoh istri } \\
\text { Ajo Sidi } \\
\text { menjadi } \\
\text { tokoh } \\
\text { perempu- } \\
\text { an. }\end{array}$ & $\begin{array}{l}\text { Latar } \\
\text { tempat } \\
\text { dan } \\
\text { waktu } \\
\text { baik } \\
\text { cerpen } \\
\text { maupun } \\
\text { naskah } \\
\text { drama } \\
\text { sama } \\
\text { yaitu } \\
\text { latar } \\
\text { tempat } \\
\text { ditandai } \\
\text { dengan } \\
\text { surau } \\
\text { dan latar } \\
\text { waktu } \\
\end{array}$ & $\begin{array}{l}\text { Te-ma } \\
\text { yang } \\
\text { ter-kan- } \\
\text { dung } \\
\text { da-lam } \\
\text { cer-pen } \\
\text { maupun } \\
\text { nas-kah } \\
\text { dra-ma } \\
\text { yaitu } \\
\text { kea-ga- } \\
\text { ma-an. } \\
\text { Karena } \\
\text { ber- } \\
\text { bica-ra } \\
\text { me- } \\
\text { nge-nai } \\
\text { iba- }\end{array}$ & $\begin{array}{l}\text { Nilai } \\
\text { amanat } \\
\text { yang } \\
\text { terkan- } \\
\text { dung } \\
\text { yaitu } \\
\text { selalu } \\
\text { menja-ga } \\
\text { keimana } \\
\text { n dan } \\
\text { ketaq- } \\
\text { waan } \\
\text { kepada } \\
\text { Allah } \\
\text { swt; } \\
\text { intros- } \\
\text { peksi diri } \\
\text { dan tidak }\end{array}$ & $\begin{array}{l}\text { Pengantar satu } \\
\text { adegan ke adegan } \\
\text { berikutnya } \\
\text { merupakan sebuah } \\
\text { isyarat ke cerita } \\
\text { berikutnya. } \\
\text { - Adegan } 1 \\
\text { Adanya pimpinan } \\
\text { pentas yang } \\
\text { berinteraksi dengan } \\
\text { pemain, mencoba } \\
\text { memberi kesan lucu } \\
\text { dan hanya bagian } \\
\text { dari prolog. } \\
\text { - Adegan } 2 \\
\text { Nyanyian dari } \\
\text { orang-orang } \\
\text { mengenai Ajo Sidi }\end{array}$ \\
\hline
\end{tabular}


BAHTERA INDONESIA:

\begin{tabular}{|c|c|c|c|c|c|c|}
\hline $\begin{array}{l}\text { sedekah dan } \\
\text { pemberian } \\
\text { orang } \\
\text { sebagai } \\
\text { upah } \\
\text { mengasah } \\
\text { pisau. Tidak } \\
\text { diingatnya } \\
\text { anak dan } \\
\text { istrinya, } \\
\text { yang dia } \\
\text { ingat } \\
\text { hanyalah } \\
\text { menyembah } \\
\text { kepada } \\
\text { Allah swt., } \\
\text { tidak ada } \\
\text { yang dia } \\
\text { lakukan } \\
\text { kecuali itu. } \\
\text { Sampai } \\
\text { suatu ketika } \\
\text { Ajo Sidi } \\
\text { mencerita- } \\
\text { kan kisah } \\
\text { Haji Saleh } \\
\text { yang masuk } \\
\text { neraka gara- } \\
\text { gara } \\
\text { menelantar- } \\
\text { kan anak } \\
\text { dan istrinya } \\
\text { padahal } \\
\text { rajin salat. } \\
\text { Hal ini } \\
\text { membuat } \\
\text { kakek } \\
\text { merasa } \\
\text { tersinggung } \\
\text { dan merasa } \\
\text { bahwa Haji } \\
\text { Saleh } \\
\text { adalah } \\
\text { sindiran } \\
\text { bagi si } \\
\text { kakek } \\
\text { karena } \\
\text { persis } \\
\text { dengan }\end{array}$ & $\begin{array}{l}\text { Sedang-kan } \\
\text { dalam naskah } \\
\text { drama tidak } \\
\text { dicerita-kan } \\
\text { langsung } \\
\text { pada inti } \\
\text { cerita. Ada } \\
\text { improvi-sasi } \\
\text { pada bagian } \\
\text { awal cerita } \\
\text { yaitu } \\
\text { pembacaan } \\
\text { doa dan } \\
\text { dialog antara } \\
\text { seorang } \\
\text { perempuan } \\
\text { dan pimpin- } \\
\text { an pentas } \\
\text { sebagai } \\
\text { prolog. } \\
\text { Kemudi-an } \\
\text { epilog juga } \\
\text { dibawakan } \\
\text { oleh pimpin- } \\
\text { an pentas. }\end{array}$ & $\begin{array}{l}\text { Penambah } \\
\text { an tokoh } \\
\text { tersebut } \\
\text { adalah } \\
\text { pembaca } \\
\text { doa 1, 2,3; } \\
\text { pendo- } \\
\text { ngeng 1,2; } \\
\text { tokoh lain } \\
\text { 1, 2, 3; } \\
\text { seorang } \\
\text { perempu- } \\
\text { an; dan } \\
\text { perempu- } \\
\text { an } 1,2,3 \text {, } \\
4 .\end{array}$ & $\begin{array}{l}\text { ditandai } \\
\text { dengan } \\
\text { perubaha } \\
\text { n hari. } \\
\text { Latar } \\
\text { tempat } \\
\text { dan } \\
\text { waktu } \\
\text { dalam } \\
\text { pertunju } \\
\text { kan } \\
\text { drama } \\
\text { membu- } \\
\text { tuhkan } \\
\text { bantuan } \\
\text { properti } \\
\text { dan tata } \\
\text { cahaya } \\
\text { jika } \\
\text { naskah } \\
\text { drama ini } \\
\text { dipentas } \\
\text { kan. }\end{array}$ & dah. & $\begin{array}{l}\text { boleh } \\
\text { som- } \\
\text { bong; } \\
\text { serta } \\
\text { hidup } \\
\text { harus } \\
\text { seim- } \\
\text { bang } \\
\text { tidak } \\
\text { hanya } \\
\text { beriba- } \\
\text { dah } \\
\text { tetapi } \\
\text { juga } \\
\text { menca-ri } \\
\text { nafkah } \\
\text { demi } \\
\text { anak dan } \\
\text { istri atau } \\
\text { keluar- } \\
\text { ga. }\end{array}$ & $\begin{array}{l}\text { yang selalu } \\
\text { menyindir orang. } \\
\text { - Adegan } 3 \\
\text { Musik bergemu-ruh. } \\
\text { - Adegan } 4 \\
\text { Permainan lampu } \\
\text { yang menyinari Ajo } \\
\text { Sidi dan musik } \\
\text { bergema. } \\
\text { - Adegan } 5 \\
\text { Musik bergemu-ruh. } \\
\text { - Adegan } 6 \\
\text { Semua orang } \\
\text { bergerak dan musik } \\
\text { bergemu-ruh. } \\
\text { - Adegan } 7 \\
\text { Musik terdengar } \\
\text { memilukan dan } \\
\text { terdengar teriakan } \\
\text { serta suara orang } \\
\text { mengaji. }\end{array}$ \\
\hline
\end{tabular}




\begin{tabular}{|l|l|l|l|l|l|}
\hline kehidupan- & & & & \\
nya. Karena & & & & & \\
terlalu & & & & \\
memikirkan & & & & \\
hal & & & & \\
demikian, & & & & \\
akhirnya di & & & & \\
surau itu & kakek & & & \\
bunuh diri & & & & & \\
dengan & pisau cukur & & & & \\
yang & & & & \\
diasahnya. & & & & \\
\hline
\end{tabular}

Model Pembelajaran Menulis Naskah Drama

\begin{tabular}{|c|c|c|c|}
\hline No & $\begin{array}{l}\text { Unsur } \\
\text { Intrinsik }\end{array}$ & $\begin{array}{c}\text { Karya } \\
\text { Sebelumn } \\
\text { ya }\end{array}$ & $\begin{array}{c}\text { Karya } \\
\text { Hasil } \\
\text { Transform } \\
\text { asi } \\
\end{array}$ \\
\hline 1. & Tema & & \\
\hline 2. & Tokoh & & \\
\hline 3. & Alur & & \\
\hline 4. & Latar & & \\
\hline 5. & Amanat & & \\
\hline 6. & $\begin{array}{l}\text { Gaya } \\
\text { Bahasa }\end{array}$ & & \\
\hline 7. & $\begin{array}{l}\text { Kebahasa } \\
\text { an } \\
\text { Pengaran } \\
\text { g }\end{array}$ & & \\
\hline
\end{tabular}

Bentuk transformasi bisa dari mengubah tema, tokoh, alur, latar, amanat, gaya bahasa, dan kebahasaan pengarang ataupun mengubah ke semua unsur tersebut. Apabila mahasiswa sudah dapat mengubah semua unsur tadi menjadi tidak sama persis dengan karya sebelumnya maka mendapatkan penilaian yang tinggi. Tetapi apabila mahasiswa masih mengubah salah satu unsur saja maka diberi penilaian yang rendah. Apabila mengubah beberapa unsur atau lebih dari satu unsur maka diberi penilaian sedang.

\section{A. Simpulan dan Saran}

\section{Simpulan}

Berdasarkan pembahasan analisis yang telah dilakukan terhadap naskah Robohnya Surau Kami dapat dirumuskan simpulan sebagai berikut.

(1) Struktur teks drama Robohnya Surau Kami memperlihatkan sebuah struktur karya sastra baru yang berbeda. Dari bentuk teks cerpen dijadikan sebuah naskah drama yang terdiri dari ikhtisar, alur, pelaku, latar, tema, nilai, sikap pengarang, dan tipe teks, berisi teks utama dan teks penunjang atau teks samping, terdiri atas tiga bagian, yaitu bagian pembuka cerita, bagian isi cerita, dan penutup cerita. Di dalamnya terdapat eksposisi, komplikasi, klimaks, resolusi, dan konklusi.

(2) Bentuk pentransformasian dari teks cerpen ke dalam teks drama meliputi: transformasi cerpen Robohnya Surau Kami ke dalam bentuk naskah drama mengubah alur, penokohan, latar, tema, dan nilai-nilai walaupun perubahannya hanya mengurangi tokoh, latar, tema, alur, dan amanat. 
(3) Hasil penelitian naskah Robohnya Surau Kami ini dapat digunakan untuk menyusun model menulis naskah drama di Universitas Wiralodra Indramayu.

\section{Saran}

Studi perbandingan sastra tradisional dengan sastra modern di Indonesia dalam bentuk transformasi merupakan studi yang masih jarang dilakukan oleh peneliti, oleh karena itu penelitian yang serius dan mendalam tentang perbandingan tersebut perlu terus digalakkan dan diberi apresiasai demi mengungkap nilai-nilai yang terkandung dalam teks sastra. Berdasarkan hasil penarikan simpulan di atas, ada beberapa saran yang ingin penulis sampaikan, sebagai berikut.

1) Pemanfaatan hasil penelitian ini tidak hanya untuk kalangan mahasiswa tetapi dapat dimanfaatkan pula untuk siswa SMP dan SMA sederajat.

2) Penelitian naskah drama Indonesia hasil transformasi dapat dimanfaatkan untuk pembelajaran sastra.

3) Penyusunan model menulis naskah drama dapat meningkatkan antusiasme mahasiswa dalam belajar, sehingga dosen dianjurkan menggunakan model ini dalam pelaksanaan pembelajaran menulis naskah drama.

4) Persiapan pelaksanaan model menulis naskah drama dalam pembelajaran menulis naskah drama harus menganalisis terlebih dahulu bentuk teks sebelumnya.

5) Model ini lebih banyak latihanlatihannya, yaitu latihan terstruktur, terbimbing, dan mandiri, maka diperlukan latihan yang keras.

6) Penelitian ini hanya digunakan dalam keterampilan yang bersifat produktif (menulis).

7) Model menulis naskah drama ini telah terbukti kebermanfaatannya, sehingga model ini dapat terus digunakan dalam setiap pembelajaran menulis naskah drama.

\section{Daftar Pustaka}

Abdullah, Imran T. (1994). Resepsi Sastra dan Penerapannya. Yogyakarta: Masyarakat Poetika Indonesia IKIP Muhammadiyah Yogyakarta.

Biran, H. Misbach Yusa. (2006). Teknik Menulis Skenario. Jakarta: Pustaka Jaya.

Damono, Sapardi Djoko. (2005). Pegangan Penelitian Sastra Bandingan. Jakarta: Pusat Bahasa Depdiknas.

Dewojati, Cahyaningrum. (2010). Drama (Sejarah, Teori, dan Penerapannya). Yogyakarta: Gadjah Mada University Press.

Elina Syarif, Zulkarnaini, Sumarno. (2009). Pembelajaran Menulis. Jakarta: Departemen Pendidikan Nasional.

Endraswara, Suwardi. (2011). Metode Pembelajaran Drama (Apresiasi, Ekspresi, dan Pengkajian). Yogyakarta: CAPS.

Esten, Mursal. (1992). Tradisi dan Modernitas dalam Sandiwara. Jakarta: Intermasa.

Harymawan. (1986). Dramaturgi. Yogyakarta: IKIP Sanata Dharma.

Hasanuddin. (2009). Drama Karya dalam Dua Dimensi (Kajian Teori, Sejarah, dan Analisis). Bandung: Angkasa.

Hidayat, Kosadi. (2009). Metodologi Pengajaran Bahasa. Bandung: Yaf Publish.

Huberman, Matthew B. Miles dan A. Michael. (2009). Analisis Data Kualitatif. Jakarta: Universitas Indonesia Press. 
Indra Tranggono, Isti Nugroho, Denny JA, dkk. (2012). Teater Monoplay dan Musikal. Jakarta: Teplok Press.

Jabrohim, Chairul Anwar, Suminto A. Sayuti. (2009). Cara Menulis Kreatif. Yogyakarta: Pustaka Pelajar.

Junus, Umar. (1985). Resepsi Sastra. Jakarta: Gramedia.

Lutters, Elizabeth. (2006). Kunci Sukses Menulis Skenario. Jakarta: Grasindo.

Maulana, Dwi. (2014). Bahasa Indonesia. Indramayu: Balai pustaka.

Minderop, Albertine. (2005). Metode Karakterisasi Telaah Fiksi. Jakarta: Yayasan Obor Indonesia.

Musthafa, Bachrudin. (2008). Teori dan Praktik Sastra dalam Penelitian dan Pengajaran. Jakarta: Cahaya Insan Sejahtera.

Nurgiyantoro, Burhan. (2009). Teori Pengkajian Fiksi. Yogyakarta: Gadjah Mada University Press.

Nurgiyantoro, Burhan. (1998). Transformasi Unsur Pewayangan dalam Fiksi Indonesia. Yogyakarta: UGM Press.

Pradopo, Rachmat Djoko. (2002). Kritik Sastra Indonesia Modern. Yogyakarta: Gama Media.

Pranoto, Naning. (2007). Creative Writing. Jakarta: Raya Kultura.

Pudentia, M.P.S.S. (1992). Transformasi Sastra: Analisis atas Cerita Rakyat Lutung. Jakarta: Balai Pustaka.

Ratna, Nyoman Kutha. (2006). Teori, Metode, dan Teknik Penelitian Sastra. Yogyakarta: Pustaka Pelajar.
Rendra. (2013). Seni Drama untuk Remaja. Bandung: Pustaka Jaya.

Riyana, Rudi Susilana dan Cepi. (2007). Media Pembelajaran. Bandung: Wacana Prima.

Rozak, Abdul. (2012). Menulis Skripsi Tidak Sulit. Yogyakarta: Framepublishing.

Semi, M. Atar. (2007). Dasar-Dasar Keterampilan Menulis. Bandung: Angkasa.

Slamet, St. Y. (2008). Dasar-dasar Pembelajaran Bahasa dan Sastra Indonesia di Sekolah Dasar. Surakarta: UNS Press.

Solehan, T.W., dkk. (2008). Pendidikan Bahasa Indonesia di SD. Jakarta: Universitas Terbuka.

Sugihastuti. (2011). Teori Apresiasi Sastra. Yogyakarta: Pustaka Pelajar.

Sugiyono. (2011). Metode Penelitian Kuantitatif, Kualitatif, dan $R \& D$. Bandung: Alfabeta.

Sumardjo, Jakob dan Saini K.M. (1988). Apresiasi Kesusastraan. Jakarta: Gramedia.

Suryaman, Maman. (2012). Metodologi Pembelajaran Bahasa. Yogyakarta: UNY Press.

Teeuw. (1984). Sastra dan Ilmu Sastra. Jakarta: Pustaka Jaya.

Waluyo, Herman J. (2002). Drama (Teori dan Pengajarannya). Yogyakarta: Hanindita Graha Widya.

Wellek, Rene \& Austin Waren. (1990). Teori Kesustraan. Diindonesiakan oleh Melani Budianta. Jakarta: Gramedia. 